\title{
THE COLLECTIVE MEMORY AS A TRAUMA FOR THE GERMAN ETHNICS FROM ROMANIA. CASE STUDY: GERMANS' DEPORTATIONS FROM BUKOWINA TO THE SOVIET UNION (1945-1949)
}

\author{
Ioana SCRIDON \\ Babeş-Bolyai University, Cluj-Napoca, ROMANIA \\ ioana.scridon@ubbcluj.ro \\ DOI: http://doi.org/10.23740/TID120172
}

\section{ABSTRACT}

This study refers to the shapes in which space and time can become traumatic memories. The venture between time and space mimes an identity breach both in the personal and collective history. The deportation represented the wound in the German history for whether Germans from Romania or from different other countries under Soviet influence at the end of the Second World War. The events that occurred during the Second World War affected the entire world and the consequences of the war were catastrophic for Germany as it was losing the war. Also the consequences of losing the war by Germany were noticed by the German ethnics who lived in the areas occupied by Russia. Germans were picked up for deportation with the sole purpose of using them for rebuilding the economy and infrastructure of the Soviet Union.

Memories of the deported, collected through interview, represent the unique source of documentary material which is also a cry for help over the drama and horrors of deportations that are now more real than ever and can be seen in physical and psychological traumas that are now visible scars.

Keywords: memory, trauma theory, deportation, survivors, place identity, homesickness, culture

\section{INTRODUCTION}

The historic events that took place in Europe during the last century, like the two World Wars, the Holocaust, treatments of water, German deportations from the Soviet influence areas during the Second World War, revolutions, but also other events, have determined the orientation of scientific research not only towards the causality of these historic episodes, but mostly towards the consequences these had when it comes to memory and collective identity. All these can be put under the same traumatic mark of the memory of the ones involved (soldiers, prisoners, deported, revolutionaries, veterans, families of the victims, etc.), but also transferring this to the generations to follow.

Deportation affected almost a quarter of a million of the German population from Romania, which during the Second World War was influenced by Romanian, German and as well Hungarian army enrolment. The trauma of these horrors represent live testimonies, lived primary sources for documentation on a history which might be different in comparison to the official one, learned in schools or read. The importance and necessity of these researches becomes more critical as the survivors of these events are less and less. The digitalization of their testimonies becomes a necessity for putting together the documents from archives. 
The problem that arises in the future, when it comes to trauma, not only refers to the trauma of the people directly involved, deported, but also of the ones left at home, Daheimgebliebenen, especially the children with deported parents, adolescents, trauma and psychological experiences, the problems they had then, but also the problems they had during their lives. In almost every German family (in many cases also in mixed marriages) from Romania, someone was deported and, in almost every family, there was a man who went at the war (Scridon, 2015, p. 201).

\section{METHODOLOGY}

The present research is based on theoretical sources from the humanist sciences domain, using specific methodology, but also on quality sources of interviews from a project started in 1990 by the Bukowina-Institut from Germany with former Bukovina people deported in the Soviet Union, between 1945 and 1949, most of them being German ethnics and Romanian citizens, living in Romania.

The primary sources of this study are represented by research made public after 1990 in Europe and refer to trauma, the theory of trauma, causality investigation, shapes of development of trauma, collective manifestations of trauma or to how exactly the trauma is the mental link of the individual with space and time. Among the remarkable papers on memory, on turning memory into a theory and its connection with history and culture it is worth mentioning Maurice Halbwachs, Pierre Nora or Jan and Alleida Assmann. These researches are pointing towards memory, remembering, forgetting or to the dependence between history and memory. History does not represent, in this case, just an event that occurred in the past, but an event that happened at some point and in a certain place. Maurice Halwachs (1950), in La mémoire collective, brings into discussion the memory trilogy, whether it is collective, historical or individual, in time and space.

Pierre Nora introduces the term of places of memory, lieux de mémoire. These refer to a social group crystalized around certain "places/lieux", with a symbolic value and with the functionality of shaping identities (Nora, 1989, p. 19).

Jan and Aleida Assmann create a theory about the entire concept of memory, entering in the structure of memory and proposing three types of memory: communicative memory, collective memory, and cultural memory. At the roots of their studies, one can find the papers of Maurice Halbwachs. Halbwachs is the one linking the memory even more, especially the cultural one, to the space which the remembered event refers to (Halbwachs, 1950, p. 93).

Other well-known studies belong to Cathy Caruth, Trauma: Explorations in Memory (1995) and Unclaimed Experience: Trauma, Narrative and History (1996). Cathy Caruth is also the author which offers trauma an essential place in the memory and not only as a starting factor for different types of changes of the relationship with the Other when it comes to identity. The theory of trauma designed by Caruth, through the delimitation of its shape, develops interesting interpretations in the academic environment of humanist sciences.

The second important pillar of the study on backing up the theory on trauma, with roots in the identity of place, is represented by 21 interviews realised between 1993 and 1997 by the director of the Bukowina-Institut from Augsburg, Dr. Ortfried Kotzian, with survivors of German deportations from Bukovina to the Soviet Union. These were published initially in the Bukovina Association newspaper from Germany, Der Südostdeutsche, and, in 2015, in a collective volume dedicated to deportations of Bukovina people, Deportation von Bukowinadeutsche in die 
Sowjetunion, with the occasion of celebrating 70 years from the deportation of German ethnics from Romania to the Soviet Union 1945-2015 (Kotzian et al., 2015).

\section{RESULTS AND DISCUSSION}

\section{The theory of trauma. Definition, limits, psychoanalysis}

Trauma represents an individual image which turns into a collective one, but without having its edges drawn very clear, especially when it refers to the psyche and subconsciousness of an individual. The theory of trauma starts from the roots of psychoanalysis theories that Sigmund Freud developed and the traumatic events as ways of reconnecting an individual with his past or moments "bringing the patient back in to the situation of his accident, a situation from which he wakes up in another fright. This astonishes people far too little" (Caruth, 2014, p. 21). Freud's concept is used in the German language as Nachträglichkeit, the importance provided not to the traumatic moment, but to the late repercussions of the moment that have destabilized the subconsciousness of the individual or of the collective.

Freud's successor in the theory of trauma is Cathy Caruth and it is one of the most influent modern voices in the matter. She describes trauma like being a rupture in the mind of the individual regarding his experience, at a certain moment. The rupture becomes a stranger in the personal experience, which leads to the instauration of dim in individual subconsciousness, which cannot relate to any other past experience to be recognized and accepted. In conclusion, trauma represents a re-run in the present of an event that happened in the past, which can lead to states of anxiety and social retreat. The force trauma develops with is a subjective one and it related to the experience of the individual, "the distances between past and present, here and another place that constitutes the force of trauma" (Caruth, 1995, p. 9).

Another definition of trauma is given by another theoretician of the subject, Lenore Terr, which defines trauma differently: "psychic trauma occurs when a sudden, unexpected, overwhelming intense emotional blow or a series of blows assaults the person from outside. Traumatic events are external, but they quickly become incorporated into the mind" (Terr, 1990, p. 8).

In its most classic and common sense, we can say trauma does not represent a harmful event, not especially; trauma can be defined both as a happy and negative event. Sandra Bloom details the mechanisms of trauma and reminds that trauma "is how the individual's mind and body reacts in its own unique way to the traumatic experience in combination with the unique response of the individual's social groups" (Bloom, 1999, p. 1).

The completion of Freud's theory was a necessity from a social-historical perspective to shape trauma and its forms and so the ethic character of research on the matter has been discussed, especially of the historical one, but with no clear limits. The sufferings and traumatic memories of the Holocaust have been an impact in the development and definition of trauma theory. Just how history indicates, many collective traumas wear the cultural and ethnic sign and the development of a mission of this kind, of defining trauma, leads to accepting a cultural-cross, but also an ethnic one (Andermahr, 2015, p. 500). Trauma represents a consequence of certain events that occurred, which transmit different thinking models from one generation to another and which, in time, can be seen, that the phenomenon is actually active and it only vanishes in appearance (Halbwachs, 1950, p. 35). 


\section{Trauma as a historical experience}

Trauma depends on the historical experience, but also on the collective one. The historical experience is defined in time and space. These delimitations are given by the importance of the moment and the place for each individual: "The traumatic event is not experienced as it occurs, it is fully evident only in connection with another place, and in another time" (Caruth, 1995, p. 4).

Germans' from Romania deportation for labour, for paying war damages by the German people to the Soviet Union, meant moving a big mass of people, from families, work places, and a move for a mandatory work. The new space (the Soviet Union, the Ural Mountains, Donbas, and Siberia) became "cold", and "unknown". The space each individual was referring to, that "home" had become the opposite. This rupture in the normal of deported German ethnics led to the transformation of the word "home" to a clear defined image, to hope and to a good reason to fight for survival.

These experiences and trauma of the deported, even if not mentioned in official documents, only in numbers, in the number of the deported, the number of the deceased, the number of the people that got back home, are part of collective history and need to be mentioned in literature, memorialistic, and scientific research.

This event of deportation, which happened during a relatively short period, in many cases "overnight", in other cases in a week, destabilized and destructured the space and time of the individual: "Her spatio-temporal definition of trauma signals the psychic gap or rupture of the mind in trauma but also hints at possible recovery; as trauma disrupts normal parameters of temporality and spatiality, repossessing time and space brings about a coming to terms with it" (Rodi-Risberg, 2010, p. 2).

Trauma can be outrun easily when it is shared with people with similar experiences and this because of an experimental experience of trauma. This way, it is established a balance between the individual psychic and the social world in which the individual comes from. In the case of the deported Germans, this happened very late (after 1989) and in very little cases (outcome of censorship). The communist system, which was already installing when returning from deportations, determined the ethnics to retreat socially inside their communities. The tightness of the system and the threats they took with them from the Soviet Union of not mentioning what happened, saying they would return to work in Siberia and in the Ural Mountains, made the ethnics introvert. On one hand, it was the fear, on the other it was the trauma under different shapes which installed in the life of each deportee.

The cultural identity and a few personal belongings the deported people took with them meant their entire interior and spiritual world, being the only orientation point in that cold space of deportation. These elements and the mental image of the family space represented a source of balance between home and camp.

\section{Psychological and individual trauma}

Psychological trauma is defined by the reaction of the subconscious when a strong event, with emotional and physical implications, results in injury or effects on the psyche. The sole story telling of trauma can be a good experiment in terms of awareness and healing or it can be an experiment of painful remembering and experiencing once again those feelings lived in the tragic past. 
The first definition and an important one in the specialised literature was given by Freud, who defined the term Nachträglichkeit like being a random memory movement, a conscious movement between two events. This also points out the critic time of psychological state at a certain moment (Rodi-Risberg, 2010, p. 1).

Trauma or the post-traumatic effects cannot be defined through the event itself, which can or cannot be traumatic (each individual is differently traumatized), but it can be defined through the distortion of the event, felt through a personal distortion and the meaning each individual gives to the event. The impact of trauma depends on the personal experience, the individual perception of trauma, which implies a subjective theory (Radstone, 2007, p. 13).

What shakes the system for an answer at the traumatic moment is fear. This leads to inhibitions and loss of control over the moment. Traumatized people have difficulties in managing their emotions and their capacity of passing over the critic moment is stopped because of uncontrollable emotions (Bloom, 1999, p. 4).

\section{Trauma: memory of time and space}

Space, a relatively general word, is differently approached in many research directions and it can have more interpretations. The most representative one refers to the place, a place in the mind of the individual, which repeats like an image of a moment with which he feels connected to through a certain memory. This place is temporarily delimited and it appears like a physical individual mark. The second sense of space refers to the mental space, the spiritual belonging to a certain space which does not exist physically, but it is an individual creation for a benchmark. Another possible interpretation of the term in this domain is space related to landscape, an image the individual is also a part of. So, the most intense connection of the individual with space is given through the photographic image on the place of the event. Caruth, points out that "to be traumatized is precisely to be possessed by an image or event" (Caruth, 1995, pp. 4-5).

The connection between memory and a place is traced using trauma and lived experiences. Trauma sends us to a space-time structure which is very complex, a certain place in a certain period of time. Whitehead claims that place was more important than time because it is the place that is brought in the present, with memories. Time remains the same, like an invariable constant. So, time is given a place and not the other way around. The place is transformed into a memory (Whitehead, 2003, p. 275).

The intensity of trauma established by Rodi-Risberg is an essential characteristic of the place at a certain point: "The spots of time protect the traumatized person from becoming too fixated on the traumatic experience or memory recall by providing some form of spatial distance to the recollections" (Rodi-Risberg, 2010, p. 184).

Caruth offers a special importance to the relationship between space and time when it comes to trauma: "Locating the memories of feelings from the past contemplated in the present, in giving them a specific place: space is fused with time and place is transformed into a demesne of memory, linked to another place and another time" (Caruth, 1995, pp. 644-645).

A possible difference between time and space is the one created by the environmental trend through which it is mentioned that time stays the same as a fix element, given, while space is a construct of each individual, created depending on his experience and expectations and it cannot be influenced in time, at least not as much as changing its structure. The authors that open this way of interpretation are Reed (2002), Whitehead (2003) and Bennett (2001). This 
theory goes on making the difference between the trauma caused by natural phenomena or by men, effects being completely opposite, indicated by the violence with which trauma effects manifest for traumatic events caused by man and the resignation in front of natural catastrophes, for example.

The trauma is the connection between space and the moment of a crisis [traumatic] (Caruth, 1995, p. 633). In this case, the trauma can be considered a continuous process between the environment/space which has started the entire process and the stress for the individual. If the individual has enough resources, whether cognitive or emotional, built in time, then he can handle that event in comparison to a person that meets with for the first time with that challenge. The intensity of the trauma of deported people is bigger for the ones in this situation for the first time, which led to the intersection between personal traumatic memories and the space in which the events occurred. Remembering the events from the deportation time for German ethnics take us to the Soviet space.

\section{Description of the traumatic experience caused by the German deportation from Bukovina (1945-1949)}

\subsection{Historic context of deportations}

The deportation of German ethnics towards the end of Second World War (January 1945), with motivation of war damage payment caused by the German troops and their allies, the Soviet Union left tracks in the deportees' conscience and memory.

The German deportation to the Soviet Union took place officially starting on the $6^{\text {th }}$ of January 1945, when the ally Commissions order is being adopted by the Control, aiming to move for labour German ethnics capable of work (Fisher, 1946, p. 314; Tirier, 2015, p. 11), German women (between 18 and 30 years old) and German men (between 17 and 45 years old) (Baier, 2015 , p. 21).There were several categories of people which were exempted, like mothers with children under 1 year, people with handicap, etc. (Scridon, 2015, p. 204). In the interviews realised for this research, but in others papers written based on interviews as well, one can see clearly that those were only directory lines and the exceptions were many more.

The political crisis in Romania from the beginning of 1945 made the deportation of Germans from the Romanian territory unnoticed, very little debated in the parliament led by Nicolae Rădescu (Baier, 2017, p. 2).

Real deportations started in January 1945 without the German ethnics knowing details about the reason of their deportation, the place where they would be deported, the works and the period they would be deported for. They knew few details of the work they were about do to and they were recommended to pack winter clothes and non-perishable foods. Transported in cattle railcars, the road to Siberia or to the Ural Mountains lasted a few weeks, the living conditions in the camp, but also the working conditions represented a psychological shock for the deported ethnics and that was why most deaths occurred in the first years of deportation. The life loss was caused by biological inadaptation to the cold, to the working conditions, to food and a generally bad living regime, in trailers not fit for living, very tough work, especially in mines, with high humidity, low temperatures $\left(-40^{\circ} \mathrm{C}\right)$, low quantity of food (sour cabbage soup with daily bread portion between 600-1000 grams, depending on the type of work). This lasted for more than three years when the work of the deportees started to be a paid one, after the monetary reform from 1948 (Tirier, 2015, p. 32). 
The deportation of German ethnics followed a five-year plan through which Germans needed to rebuild ruined factories which were not working properly or to extend the ones capable of improving the economy, to open or to re-establish water connections with mine centres from Dobas with other cities or to work in agriculture. The number of deported ethnics, only from Romania, was 75.000 or maybe even 97.762 according to the German press's estimation at the time (Muradin, 2015, p. 43).

\subsection{Trauma of space and time}

Deportations were, without a doubt, major changes in the lives of the people involved in the deportation process. Irrespective of the direct effects felt through cold, starvation, fear or of the indirect ones, respectively homesickness, trauma memories started existential crises which exceeded thanks to the hope of going back home. The deportees had become victims and killed themselves or got sick. Deportation represented, at an individual level, a destruction of a social-cultural structure which usually sustained the identity of a person and put him face to face with unprecedented psychological challenges" (Păun et al., 2009, p. 2). Mathias Kandler, in the memorialistic paper writes: "The deportation to Russia in 1945 was sadder and more brutal than many people could imagine. Who can comprehend the pain of separation from the family, often leaving behind a small child, the humiliations and the hunger behind the barber wire? Death was constant companion" (Spiridon, 2013, p. 133 apud Kandler, 2009).

Memoirs, some written and then spread everywhere, others kept hidden in a terrible unhappiness, leave behind more and more brutal events of the history of a lived and unwanted war. Interviews with deportees or closed ones described ways through which traumatic memories were "attacked" after returning from deportation through threats of the Romanian authorities about sending them back to the Soviet Union for work, or family understanding of not putting children through the pain of remembering and leaving behind a past that cannot be changed and which does not have the power to change something in the present or future (Kotzian et al., 2015, p. 149, p. 151; Scridon, 2015, p. 222; Scridon, 2016, p. 492).

What deportation meant for the majority of German ethnics deported for work in the Ural Mountains and Siberia cannot be described in words, it can only be inferred from the words and the clear memories relived in every interview or memoir. Nothing from the stolen years of the people forming a young generation with the war that was not theirs cannot change not even one small part of the suffering. The unhuman situations, desolation, anxiety or fatigue were some of the reasons which led to more than a quarter of the deportees not to return to their families and so their survivors to be followed by the trauma their entire lives. War ending or returning from camps did not mean forgetting, but reliving the trauma through remembering.

Hell is the others, a phrase borrowed by Halbwachs from Sartre, shows very well the fact that forgetting is independent from the individual that has lived a traumatic experience, but the presence the to other deported people activates the memories for that particular individual. As a theory, forgetting was described and interpreted by many psychologists, sociologists or anthropologists to be a necessary and very useful phenomenon for the memory.

Place and space during deportation played an unhappy role, a role of leaving the normality from "home", the environment German ethnics were used to, each in the towns and families they were living in. If their experiences were understood as trauma after returning home, their survival was assured by other images they projected as being part of the family home. In their worst moments, they declared that they were thinking about their children waiting for them at 
home, children left in the care of the grandparents or neighbours. They were also thinking about their parents waiting for them or other dear ones.

The image of the "place", of what they knew as "home" during deportation, became more and more familiar, common, and managed to become hope. The fact that the mind was not able to recognize the new living deportation conditions, in comparison to the ones from "home", determined a moment of crisis after returning from deportation.

The new situations and the work conditions determined a coordination between Germans in camps, forming groups. The groups were formed between relatives or neighbours until survival became a purpose itself. The necessary resources for this were finding an interior motivation force and a mechanism able to accept the present.

\begin{abstract}
"I had typhus and ague. But I always said I will manage to get back home again. I was not afraid. I missed only one person, a young woman from Suceava. She died there. She was the only one buried in normal conditions. She was young and beautiful. Others were just covered with a wool blanket and thrown in a whole." (Stefanie Ostapowicz, Kotzian et all., 2015, p. 100)
\end{abstract}

The biggest enemies were cold, hunger and fear which brought to light the deportees' primary instincts. The majority of the interviewed people were asked regarding the climate conditions from the region they had been deported to and if these had influenced in any way the rest of their lives. With no exception, the deportees described with very specific details, especially the winter times, the work conditions in this season. During winter time, the cold and especially the slow adaptation of the ethnics to the new climate conditions remained in their memory. Physical evidence of trauma are actually connections with the past. These memories are so deep in the former deportees' subconsciousness that each memory was expressed using "It's like I feel cold right now":

"In this camp (n.r. Kubadnik) everything was frozen. A big cold was ruling here." (Gizela Neudeck, Kotzian et al., 2015, p. 45)

"I remember the terrible cold from Rikiteanka. There have been even $-50^{\circ} \mathrm{C}$. ... I volunteered to bring water from the fountain. My nose was almost frozen. I had to put snow on it fast. I can almost feel that now." (Elfriede Polluch, Kotzian et al., 2015, p. 54)

"There (n.r. Kubadnik) was very cold, everything was frozen. I got a face mask and it was open just around my eyes. I worked in a mine there and in a cement factory. Then I got typhus. I had bandages around my head. I had a foot infection which bothers me even today. I got it from a freezing or infection. I went through terrible moments. Regarding food, we only received $100 \mathrm{~g}$ of bread per day." (Ludmila Popovicz, Kotzian et al., 2015, p. 57)

"Day and night, I cleaned dirt with a shovel. At $-35^{\circ} \mathrm{C}$ in the camp, we received wet, cold clothing and there was no heat. I worked there for 3 years at the railway. We were shaken by the cold." (Martha Filip, Kotzian et al., 2015, p. 104)

Another perception on camps and works during deportation was hunger. Except the Bukovina respondents, one German from Banat interviewed with a different occasion (2014, theme: the woman condition in Soviet deportation camps - Scridon, 2015), which now lives in a retirement home in Germany (Augsburg) said that the worst problem in the home is the little bad food. These declarations turned out to be not true, but were coming from the person's subconsciousness, who still had the image of the life during deportation where the biggest problem she had back then was hunger. Actually, hunger is the main theme of discussion in Herta Müller's novel, Atemschaukel. Hunger was actually a tentacle of the survival instinct. The 
deported started looking for food even in the places garbage was stored, on the field digging for remaining potatoes and roots and begging in villages found near the camps.

"Food was bad, very bad and little, nettle soup. Hard work and big cold." (Hedwig Kipper, Kotzian et al., 2015, p. 113)

"We were always thinking about food because we always got very little. They threatened us with no returning to our homes." (Anna Bodnărescu, Kotzian et al., 2015, p. 147)

Forgetting those events is impossible for deported people. The trauma followed them their entire life and managed to dictate the way they manifested themselves, for example buying and handling groceries, dressing or socialising. Herta Müller said, on different occasions in public, while talking about her mother who was deported, that the cold in her behaviour created a distance among the members of the family. Also, deported women from Nitchidorf, from Banat, Timiş County, were easily recognised thanks to their dark colour clothing, even if not black, short hair, always thinking, anxious, agitated, the speed they worked with or the isolation from society. Even after they were released, the familiarity with the camp, the discretion, obedience or respecting the silence was kept in a certain way in the day to day life of the deported.

"This cannot be forgotten, but with time, with work and family, not everything was as bad. We were already used with this." (Ludmila Popovicz, Kotzian et al., 2015, p. 59)

"In our camp there has been a 20 year old girl from Focşani who only lived in the camp for two months. She did not have enough clothes, got a cold and died. This got stuck in my mind because there you were thrown in a hole and that was all." (Stefanie Costiniuk, Kotzian et al., 2015, p. 65)

"I buried my brother there. Not in the ground, he froze at $-45^{\circ} \mathrm{C}$. I laid him near a tree. After twenty days I went to see him, but wolves have devoured him. There were only bones. It was awful." (Martha Filip, Kotzian et al., 2015, p. 105)

Some people never succeeded to detach from that terrible period of their lives. The traumatic experience was present in their dreams or manifested in unusual conditions which took deported thinking about their years in the Soviet Union.

"The worst thing now is remembering those times lived there." (Anna Bodnărescu, Kotzian et al., 2015, p. 149)

"I always kept asking myself: Am I still there or am I home? [...] It affects me that I got sick. I have a heart condition and my knees hurt. I have kidney stones. But life goes on. [...] When I see a police man coming towards me, I get scared. When my grandmother lived she was always saying: Now his coming to take me too." (Paula Carpiuc, Kotzian et al., 2015, p. 156)

Physical trauma left many unhealed physical traces which reminded deportees of that period. The diseases they had, the harsh conditions put their imprint over their body. Having in each part of your body the cold and diseases caught in Siberia represents bravery and resistance of the individual throughout life:

"Always, from then till now, I have had headaches. [...] I have frequent dreams that I am there and I never come back home. [...] it was the hardest time of my life [...] from headaches and other weaknesses I caught rheumatism in my legs and arms. [...] my health was ruined." (Ludmila Popovicz, Kotzian et al., 2015, p. 59)

"In 1975/76 I got Parkinson. This is how the hard times in my life started. The doctor believed this appeared because of the lack of food in the camp." (Anna Bodnărescu, Kotzian et al., 2015, p. 151) 
"I was very sick. I had no period. Three and a half years, while I was there and one year after I got back. This might be the reason for my disease." (Paula Carpiuc, Kotzian et al., 2015, p. 154)

The mental was sustained by the hope of returning home, the image of the past, a past they never found when back to Romania. "The deportation to Russia became embedded in the conscience of the German community as the moment of the breach of trust from Romania, even though the misappropriation of their entire property in rural regions carried out by the first communist-dominated government in March 1945 had even more profound consequences for the social structure and transformation of the communities" (Baier, 2015, p. 23).

"It was very hard. Each person wanted to have a piece of clothing to put on. When I got home I had nothing to wear. What was I to do? I had to eat. How am I to solve this? The others were looking at me - Look, this one came from Russia! - it was hard for me. It took a lot of time, it does not pass that easily." (Stefanie Costiniuk, Kotzian et al., 2015, p. 65)

The trauma installed in the physic and psychic (Luckhurst, 2008, p. 3). As long as work was exhausting, the meals were poor, the psychic was to be trusted and learned the behaviour of the survivors from the camp. Deportees were frightened through physical and psychological violence. People forgot to be humans and lost their personal identity. The environment was so hostile that escaping was not a solution. This types of behaviours they were used to, humiliation during transportation to the camps, the selection, and the behaviour of the guards were all moments of normality during life there. On the one side, it was the high self-esteem Germans had in comparison with other ethnic groups and, on the other hand, there were the uncomfortable situations for the human mind, respectively the humiliation by deportation. For understanding the Germans' humiliation and shame, we must mention their reputation for being clean and civilized, unlike their conditions in the camp (Clit, 2012, p. 43).

"We all had the same rights, just that we could not be free. The worst thing was that we had to bury our colleagues... we had to bury them naked. After coming from work we used to dig holes to bury them in the next evening. There were no coffins, as there was no wood. The Russians were doing it the same way. They let them with their clothes on, we used to take even their shirts. There was no sense of guilt there, or sorry. We only let them in their underwear." (Karl Lemny, Kotzian et al., 2015, pp. 73-74)

The inside world of the traumatized man was not one of outbursts, of not feeling thankful, but more of feelings with no feeling, no trace of revenge (Radstone, 2007, p. 20). After the release, deportees accepted their condition and built their life on dignity.

"Yes, it was the toughest period of my life. I lost all my youth there. The best I had was left there. And I was never angry about this." (Stefan Spătaru, Kotzian et al., 2015, p. 95)

The trauma has erased any trace of guilt, resentment for that period. The subconsciousness had to replace that period with "it was God's will" or "this was meant to be, but let it not happen again" or "we were too small to change something."

"That burden exists today." (Martha Filip, Kotzian et al., 2015, p. 107)

Question: “Did you return to your print shop?"

Answer: "No, because they took everything. Home, the company, there was nothing left. My mother and sister were still there."

Q: "Did you get your home back?"

A: "No, we remained in the same house, but it was an empty house, with nothing inside. No table, no bed, no chair, nothing!" (Alfred Blodowski, Kotzian et al., 2015, p. 82) 
Sufferings followed the deportees all their lives. They lived between psychological and physical healing, in the new environment in which German ethnics were after 1949. During communism, almost 40 years, deportation was a topic never discussed among people or by the Romanian media. The press announced the deportation in 1945 in Scânteia newspaper and in other local newspapers too, the church asked that German Romanian ethnics to be taken to Romania and not Germany, especially the sick ones, and it was also the press that announced the return from the Soviet Union. After the closing of those events, this subject was never opened again. Among survivors, discussions about the years in the Soviet Union have been held in-house (Muradin, 2015, p. 47).

\section{CONCLUSIONS}

Germans' deportation to the Soviet Union was one of the darkest periods of all times in the history of Germans from Romania. This piece of history is being studied in the academic world with special focus on the memory of the deported Germans and their families. The time of deportation and the space of deportation are key points in the collective memory of deportees and an important source of keeping these memories with a collective value.

Time represented the balance between the past and the present of the traumatic event and space represents "a physical place", which empowers trauma and determines an image with traumatic value for deportees. Overcoming the physical condition was possible through putting time and space in an imaginary dimension, ideal in relationship with the familiar space.

The traumatic memories are part of the individual identity. Even if these happened in the past, they have been reactivated in the present by the ones around that person. The identity of deported survivors from Bukovina carry the elements of the trauma through shapes of dealing with the traumatic event of deportation and each interview of the research or any other discussion on deportation was a traumatic real time.

Irrespective of the type of trauma, whether it is the individual one, described through fear, or the collective one, deportation and detention represent ways of depriving people of their freedom and human dignity, having a strong negative impact on their development, whether physical or mental.

\section{REFERENCES}

ANDERMAHR, S. (2015). Decolonizing Trauma Studies: Trauma and Poscolonialism - Introduction. Humanities, 4, 500-505.

BAIER, H. (2015). The Deportation of German from Romania to Forced Labour in the Soviet Union. In: D. URSPRUNG (ed.), Euxeinos. Governance and Culture in the Black Sea Region, 19-20, 20-26.

BAIER, H. (2017). Deportation löste fast Regierungskrise aus. Ein unbeachtetes Dokument gibt Aufschluss über die Einstellung der rumänischen Politiker im Januar 1945, Retrieved January 17 2017, from http://www.adz.ro/meinung-und-bericht/artikel-meinung-und-bericht/artikel/deportationloeste-fast-regierungskrise-aus/

BENNETT, M. (2001). From Wide Open Spaces to Metropolitan Places: The Urban Challenge to Ecocriticism. ISLE: Interdisciplinary Studies in Literature and Environment, 8(1), 31-52. 
BLOOM, S.L. (1999). Trauma Theory Abbreviated. From the Final Action Plan: A Coordinated CommunityBased to Family Violence. Attorney General of Pennsylvania's Family Task Force, Retrieved January 17 2017, from http://www.dhs.vic.gov.au/_data/assets/pdf_file/0005/587966/trauma_theory_abbreviated_sa ndra_bloom.pdf

CARUTH, C. (1995). Trauma: Explorations in Memory. Baltimore: John Hopkins University Press.

CARUTH, C. (1996). An Interview with Geoffrey Hartman. Studies in Romanticism, 35(4), 631-652.

CARUTH, C. (2014). Parting Words: Trauma, Silence, and Survival. New York: Cornell University Press, Retrieved January 13 2017, from https://www.fus.edu/intervalla-files/vol2/3-CC.pdf

CLIT, R. (2012). Trauma experienței de lagăr de muncă sovietic în descrierea Hertei Müller. Collective and exemplary memories. Public and private forms of commemoration. Societal and Political Psychology International Review, 3(2), 43-54.

FISHER, P. (1946). Reparation Labor. A Preliminary Analysis. The Quarterly Journal of Economics, 60(3), 313-339.

HALBWACHS, M. (1950). La mémoire collective. Paris: PUF.

KANDLER, M. (2009). Nr. 657. Im Donbass deportiert: 1945-1949 Russlanderinnerungen. VillingenSchwenningen: Farca.

KOTZIAN, O., SCRIDON, I., \& GEIER, L. (2015). Dokumentation: Zeitzeugen der Bukowina berichten. Hermannstadt: Honterus.

LUCKHURST, R. (2008). Trauma Question. London \& New York: Routledge, Taylor \& Francis.

MURADIN, J.K. (2015). The Deportation of Germans from Romania to the Soviet Union in 1944-1945. Acta Universitatis Sapientiae, European and Regional Studies, 7, 41-49.

MÜLLER, H. (2009). Atemschaukel. München: Karl Hanser Verlag.

NORA, P. (1989). Between Memory and History: Les lieux de Mémoire. Representations. Special Issue: Memory and Counter-Memory, Spring Edition, 7-24.

PĂUN, M.A., MATEI, A., ALBU, L., NIȚULESCU, M., \& MANEA, Ș. (2009). Specificul consilierii psihologice în cazul refugiaților. Bucharest, 24 September 2009, Retrieved January 10 2017, from http://www.jrsromania.org/fisiere/Specificul\%20consilierii\%20psihologice\%20in\%20cazul\%20ref ugiatilor.pdf

RADSTONE, S. (2007). Trauma Theory: Contexts, Politics, Ethics. Paragraph, 30(1), 9-29.

REED, T.V. (2002). Toward an Environmental Justice Ecocriticism. In: ADAMSON, J., EVANS, M.M., \& STEIN, R. (eds.), The Environmental Justice Reader: Politics, Poetics, \& Pedagogy (pp. 145-161). Tucson: University of Arizona Press.

RODI-RISBERG, M. (2010). Writing Trauma, Writing Time and Space. Vaasa: University of Vaasa Press.

SCRIDON, I. (2015). Frauen in der Sowjet-Deportation und "Russlandkinder". In: KOTZIAN, O., SCRIDON, I., \& GEIER, L. (eds.), Deportation von Bukowinadeutschen in die Sowjetunion (pp. 201-222). Hermannstadt: Honterus.

SCRIDON, I. (2016). Condiția femeii în lagărele de muncă din Uniunea Sovietică. Studiu de caz: Deportarea germanilor din Bucovina. Analele Bucovinei, 46(1), 201-222.

SPIRIDON, O. (2013). From Fact to Fiction: Herta Müller's Atemschaukel. In: BRANDT, B., \& GLAJAR, V. (eds.), Herta Müller: Politics and Aesthetics (pp. 130-152). Lincoln and London: University of Nebraska Press.

TERR, L. (1990). Too Scared to Cry: Psychic Trauma in Chlidhood. New York: Harper \& Row. 
TIRIER, P. (2015). Deportation von Rumäniendeutschen in die Sowjetunion 1945. In: KOTZIAN, O., SCRIDON, I., \& GEIER, L. (eds.), Deportation von Bukowinadeutschen in die Sowjetunion (pp. 1139). Hermannstadt: Honterus.

WHITEHEAD, A. (2003). Geoffrey Hartman and the Ethics of Place: Landscape, Memory, Trauma. European Journal of English Studies, 7(3), 275-292. 